\title{
ROLE AND POSITION OF R\&D UNITS IN THE CONSTRUCTION MANAGEMENT INDUSTRY
}

\author{
MOMAYEZ Ayatollah \\ Department of Civil Engineering, University of Tehran, Tehran, Iran, e-mail: amomayez@ut.ac.ir
}

Received: 05.03.2019 / Accepted: 11.04.2019 / Revised: 08.05.2019 / Available online: 31.05.2019

DOI: 10.2478/jaes-2019-0012

KEY WORDS: research and development, construction industry, construction management, culture.

\begin{abstract}
:
Today, research and development (R\&D) indices are significant criteria for the development of countries. Therefore, the objective of the present study was to investigate the role and position of research and development units in construction industry from the perspective of construction management. The study is a descriptive survey research. The statistical population comprised the elite members and experts of research and development working in this field who were 81 individuals in total. The study employed Cronbach's alpha to determine the reliability of the questionnaire. The study also exploited expert judgments of the elite members and experts of research and development in the construction industry to determine the validity of the questionnaire. For data analysis, the study deployed SPSS program. The findings reveal that the challenges existing in research and development centers are divided into the two groups of internal organizational problems and external organizational problems, and it is economically feasible to establish research and development units in the construction industry. In this regard, with a systematic view, the issue of research culture is proposed as the central point of the model.
\end{abstract}

\section{INTRODUCTION}

Today, considering the world's need to industrial competition, the producers and suppliers of goods and services are in a competition with their rivals. In this competition, the winners are those industries and countries which can have more efficient management, superior products, and more appropriate conditions. Whereas today the $\mathrm{R} \& \mathrm{D}$ indices are considered important criteria for the countries' development, and the developed countries highly value the innovation of young proficient individuals (Bosworth, 1993). In most developing countries including Iran - this index constitutes an insignificant part of the GNP. On the other hand, one of the principal challenges which management will face in the next decade and at the beginning of the 21 st century will be the development and increase of intellectual labourers at economic agencies (Salehi and Banisi, 1996). International competitiveness of a modern economy is defined through its ability to produce, attract, and commercialize knowledge (Heininger, 1988). Although this issue is not comprehensive, it has been proven that scientific and technological knowledge has a significant and valuable role in determining the countries' challenges in facing areas such as sustainable management, economic growth, health, and agricultural production, so much so that countries achieve their benefits form the research and development of foreign activates (Pery and Grinakar, 1994). Today, the performance of R \& D activities is not considered as costs. Rather, it is viewed as a sort of investment such that the amount of this investment at the level of agencies and at countries' national level is increasing daily, to the extent that the amount of investment in this area is an indicator for the development of agencies and countries in the world (Griliches, 1980).

In today's world, one of the challenges faced by the developing countries (including Iran) is to set in motion the wheels of growth and development. According to UNESCO's statistics, in 1990, the developed countries enjoyed 95-97 percent and the developing countries 3-5 percent of the research budget in the world. The same investigation reveals that each dollar spent in research and development between 1970 and 1975 has an extra benefit of 3.80 dollars while, in Iran, this benefit was 0.395 percent for state institutes and 0.0044 percent of the production for non-state ones (Shahabadi, 2002). Therefore, with the increase of population and the development of cities, new need are creates. Hence in order to provide these needs, attention must be paid to research and development in different areas. For this reason, investigation of the role and position of R \& D units in the construction industry creates an unprecedented measure in the construction management and, by blending innovative and operational plans, new achievements can be made (Shebli, 1996).

The conducting of broad research on the role and position of $\mathrm{R}$ \& D units in the construction industry and awareness of their advantages and restrictions in this area and the publication of the research findings can not only help establish an information vacuum, but, by completing related studies and using these methods, continuous temporal and economic damages could also be prevented. Therefore, the present research has enough significance and necessity to be conducted. Hence, this research 
attempts to investigate the role and position of $\mathrm{R} \& \mathrm{D}$ units in the construction industry from the perspective of construction management, and the feasibility of the use of this issue.

\section{TITLE AND ABSTRACT BLOCK}

Research and development is activity done to regularly increase scientific resources, technical knowledge, and the use of this knowledge in inventions and new functional plans. The process of research and development includes identification of requirements or talents; identification of thoughts; design, production, introduction, and release of a product or new technological system. UNESCO defines research and development as: any kind of coherent, creative activity to advance science and knowledge (including knowledge related to humans, culture, and society) and the use of this knowledge for new uses (McLaughlin, 1995).

\subsection{Types of research and development}

In a report entitled measuring knowledge and technical activities, OECD institute classified R \& D activities into the three categories of basic, applied, and developmental research.

Basic research: This research does not yield definite knowledge or a clear function. Rather, they offer new hypotheses, and general rules and theories. The findings resulting from such research are usually unchangeable and are published in scientific journals or are used by research centers. Basic research divides into the two subcategories of pure basic research and direct basic research (Northrup, 1998).

Applied research: This type of research includes main investigations in order to obtain new knowledge and is basically done to achieve certain scientific objectives, applied discovery of research findings, or pre-made issues. Such research is mainly done by industries and lavatories of state institutes, as well as academic research systems (Behkish, 2002). This type of research is mainly practical and applies basic and fundamental achievements (Ahmadi, 1998).

Developmental research: This category of research is mainly based on existing knowledge and the use of scientific research and experiences and principally seeks to improve or produce new forms of substances, products, instruments and devices, services, systems, or methods, and to plan the development of the process and similar cases. This research is usually conducted by industries or state institutes, and receives $80-90$ $\%$ of the research budget of the industries and institutes (Gazrani, 1992).

All the three type of research are components of innovation process, and each stage serves as a source of knowledge and significant and valuable input -which is the origin of new ideasto enter the next stage.

\section{RESEARCH QUESTIONS}

The present research attempts to investigate the role and position of $\mathrm{R} \& \mathrm{D}$ units in the construction industry form the perspective of construction management. For this purpose, the following research questions are investigated:
- To what degree is the use of $\mathrm{R} \& \mathrm{D}$ units in the construction industry technically and executively feasible from the perspective of construction management?

- To what degree is the use of $\mathrm{R} \& \mathrm{D}$ units in the construction industry economically feasible?

\section{METHODOLOGY}

This study is applied research in terms of function and mixed (qualitative and quantitative) research in terms of the data collection method. The population is divided into two groups. One group comprises the elite members and experts working in the construction industry. In this regard, there were deep interviews with 12 experts. Besides, a focus group was formed based on the pertinence in technical, cultural, and commercial groups. The other group of the population comprises elite members, experts, and managers in the field of construction industry. The research tools comprise two structured questionnaires administered in the filed method. The sample size in the first questionnaire was taken as 44 , and in the second questionnaire as 37 individuals. (Eq. 1 Cochran formula).

In the field research, by using the Cochran formula, the sample size was taken as 81 individuals. According to the quantitative data, the variance of the population was calculated by the SPSS program.

In order to increase the validity of the questionnaires, first they were distributed among 30 members of the population. Then, using the statistical and analytic results of the questionnaires, the elite members of industry and university professors confirmed their content validity.

This study employed Cronbach's alpha to measure the internal consistency of the measurement tool (e.g. the questionnaire). The Cronbach's alpha coefficient was calculated at 0.774 in the first questionnaire, and 0.712 in the second one. This indicates that the research questionnaires enjoy appropriate reliability and the results obtained from them are reliable.

Population of the first questionnaire:

$$
n=\frac{t^{2} p q N}{t^{2} p q+d^{2} N}=44
$$

Population of the second questionnaire:

$$
n=\frac{t^{2} p q N}{t^{2} p q+d^{2} N}=37
$$

\section{METHODOLOGY}

\subsection{Findings of the qualitative stage}

Table 1 illustrates the demographic characteristics of the respondents. Among samples of 81 individuals, 64 individuals were men and the rest were women. These individuals in average have a bachelor's degree. Individuals aged 28 to 52 participated in responding to the questionnaires $25.7 \%$ of the 
sample individuals held a bachelor's degree, $70 \%$ had a master's degree, and $4.3 \%$ had a Ph.D. degree. Also, $50 \%$ of the sample individuals were 25 to 30 years old, $37.2 \%$ were 31 to 35 , and $12.8 \%$ were over 35 years old.

\subsection{Findings of the quantitative stage of the research}

Following the interviews with the elite members and experts in the construction industry and the conceptualization of the data of the interviews, two questions were posed. In this section, for research of usefulness and brevity, the final research findings in each stage are mentioned.

The first question: To what degree is the use of $\mathrm{R} \& \mathrm{D}$ units in the construction industry technically and executively feasible from the perspective of construction management?

To answer to this question, three factors (manager's required readiness, cultural structures, and physical structures) were taken into consideration. In order to measure the effect of each of these three components on the use of R \& D units, the singlesample T-test was conducted. Therefore, the hypotheses made to provide answers to the first question are as follows (table 1):

Table 1. Demographic characteristics of the sample of the questionnaire's section

\begin{tabular}{|c|c|c|c|c|c|}
\hline \multicolumn{2}{|c|}{ Subject area } & \multicolumn{2}{|c|}{$\begin{array}{c}\text { First } \\
\text { questionnaire }\end{array}$} & \multicolumn{2}{|c|}{$\begin{array}{c}\text { Second } \\
\text { questionnaire }\end{array}$} \\
\hline & variable & $\mathrm{f}$ & $\%$ & $\mathrm{f}$ & $\%$ \\
\hline \multirow{2}{*}{ Gender } & Male & 34 & 77.3 & 30 & 81.1 \\
\hline & Female & 10 & 22.7 & 7 & 18.9 \\
\hline \multirow{4}{*}{ Education } & Diploma & 0 & 0 & 0 & 0 \\
\hline & $\mathrm{BA}$ & 21 & 47.7 & 23 & 62.2 \\
\hline & MA & 23 & 52.3 & 10 & 27.8 \\
\hline & $\begin{array}{l}\text { MA and } \\
\text { above }\end{array}$ & 23 & 52.3 & 4 & 10 \\
\hline \multirow{5}{*}{ Age } & $\begin{array}{l}21-30 \\
\text { years old }\end{array}$ & 8 & 18.2 & 8 & 21.6 \\
\hline & $\begin{array}{l}31-40 \\
\text { years old }\end{array}$ & 21 & 47.7 & 8 & 24.3 \\
\hline & $\begin{array}{l}41-50 \text { years } \\
\text { old }\end{array}$ & 15 & 34.1 & 10 & 27 \\
\hline & $\begin{array}{l}50 \text { years } \\
\text { and older }\end{array}$ & 0 & 0 & 6 & 16.3 \\
\hline & unanswered & 0 & 0 & 4 & 10.8 \\
\hline
\end{tabular}

f: frequency

First hypothesis: Required readiness in managers of organizations working in the construction industry for establishing R \& D units is at an optimal level. The test of the above hypothesis is statistically defined as follows:

$$
\begin{aligned}
& H_{0}: \mu \leq 3 \\
& H_{1}: \mu \succ 3
\end{aligned}
$$

$\mathrm{H}_{0}=$ required readiness in managers of organizations working in the construction industry is at an optimal level.

$\mathrm{H}_{1}=$ is the lack of optimality of managers of organizations working in the construction industry.

According to Table 2, the mean of managers' required readiness is below the average level (2.908), and the significance level ( $p$
$=0.440>0.05)$ and the obtained statistic $\mathrm{t}(-0.78)$ are smaller than the $t$ of the table (1.645). Therefore, there is no reason to reject the $\mathrm{H} 0$. Hence, non-optimality of readiness in managers of organizations working in the construction section for establishing R \& D units is accepted.

Table 2. Single-sample $t$ test for the importance of creating grounds to keep pilgrims longer

\begin{tabular}{|c|c|c|c|c|c|}
\hline Factor & Mean & $\begin{array}{c}\text { Standard } \\
\text { deviation }\end{array}$ & $\begin{array}{c}\text { Degree of } \\
\text { freedom }\end{array}$ & $\mathrm{T}$ & $\begin{array}{c}\text { Significance } \\
\text { level }(\mathrm{p})\end{array}$ \\
\hline $\begin{array}{c}\text { Required } \\
\text { readiness } \\
\text { in } \\
\text { managers }\end{array}$ & 2.90 & 0.769 & 42 & $\begin{array}{c}- \\
0 .\end{array}$ & 0.44 \\
\hline
\end{tabular}

Second hypothesis: The position of cultural structures for establishing R \& D units in organizations in at an optimal level. The test of the above hypothesis is statistically defined as follows:

$$
\begin{aligned}
& H_{0}: \mu \leq 3 \\
& H_{1}: \mu \succ 3
\end{aligned}
$$

$\mathrm{H}_{0}=$ non-optimality of the position of cultural structures for establishing R \& D units in organizations.

$\mathrm{H}_{1}=$ optimality of the position of cultural structures for establishing R \& D units in organizations.

$\mathrm{H}_{1}$ states that the position of cultural structures for establishing $\mathrm{R} \& \mathrm{D}$ units in organizations is at an optimal stage, and $\mathrm{H}_{0}$ assumes lack of optimality of the position of cultural structures for establishing R \& D units in organizations.

According to the results illustrated in Table 3, the mean of the position of cultural structures in below the average level (3.542), and the significance level $(\mathrm{p}=0.000<0.05)$ and the obtained statistic $t(6.514)$ are greater than the $t$ of the table (1.645). Hence $\mathrm{H}_{0}$ is rejected, and $\mathrm{H} 1$-assuming that the position of cultural structures for establishing $\mathrm{R} \& \mathrm{D}$ units is at an optimal level- is accepted.

Table 3. Single-sample T-test related to the position of cultural structures

\begin{tabular}{|c|c|c|c|c|c|}
\hline Factor & Mean & $\begin{array}{c}\text { Standard } \\
\text { deviation }\end{array}$ & $\begin{array}{c}\text { Degree } \\
\text { of } \\
\text { freedom }\end{array}$ & $\mathrm{T}$ & $\begin{array}{c}\text { Significance } \\
\text { level }(\mathrm{p})\end{array}$ \\
\hline $\begin{array}{c}\text { Position } \\
\text { of } \\
\text { cultural } \\
\text { structures }\end{array}$ & 3.542 & 0.546 & 42 & 6.514 & 0.000 \\
\hline
\end{tabular}

Third hypothesis: The presence of physical structures for establishing R \& D units in organizations in at an optimal level. The test of the above hypothesis is statistically defined as follows:

$$
\begin{aligned}
& H_{0}: \mu \leq 3 \\
& H_{1}: \mu \succ 3
\end{aligned}
$$

$\mathrm{H}_{0}=$ non-optimality of the presence of physical structures for establishing R \& D units in. 
$\mathrm{H}_{1}=$ optimality of the presence of physical structures for establishing R \& D units in organizations.

According to the results presented in Table 4, the presence of physical structures is above the mean level (3.782); the significance level $(\mathrm{p}=0.000<0.05)$ and the obtained test statistic $t$ (8.443) is greater than the $t$ of the table (1.645). Therefore, $\mathrm{H}_{0}$ is rejected, and $\mathrm{H}_{1}$ assuming that the presence of physical structures for establishing $\mathrm{R} \& \mathrm{D}$ units in the construction industry is at an optimal level is accepted.

Table 4. Single-sample T-test related to the existence of physical structures

\begin{tabular}{|c|c|c|c|c|c|}
\hline Factor & Mean & $\begin{array}{c}\text { Standard } \\
\text { deviation }\end{array}$ & $\begin{array}{c}\text { Degree } \\
\text { of } \\
\text { freedom }\end{array}$ & $\mathrm{T}$ & $\begin{array}{c}\text { Significance } \\
\text { level (p) }\end{array}$ \\
\hline $\begin{array}{c}\text { Existence } \\
\text { of } \\
\text { physical } \\
\text { structures }\end{array}$ & 3.782 & 0.608 & 42 & 8.443 & 0.000 \\
\hline
\end{tabular}

As revealed by Tables 2, 3, and 4, the required readiness of the managers of the organizations working in the construction industry for establishing R \& D units was not at an optimal level, but the impact of the existence of physical structures for $\mathrm{R}$ \& D units in the construction industry and cultural structures was at an optimal level.

The second question: To what degree is the use of $\mathrm{R} \& \mathrm{D}$ units in the construction industry economically feasible?

To answer this questions, six components.

1. advancement of innovation in products

2. reduction of waste in products

3. expansion of the market for products

4. advancement of the quality of products

5. competitive power of products

6. increase of revenue from products' sales are taken into consideration.

To measure each of these six factors in the economic feasibility of the use of R \& D units in the construction industry the single-sample T-test was conducted. If each of the six factors is above the optimal level, the use of $\mathrm{R} \& \mathrm{D}$ units in the construction industry is proven to be economically feasible.

To investigate the second question, 6 factors are investigated:

1. Advancement of innovation in products

2. reduction of waste in products

3. Expansion of the market for products

4. Advancement of the quality of products

5. Competitive power of products

6. Increase of revenue from products' sales

For each of the above factors, the following statistical test is taken into consideration:

$$
\begin{aligned}
& H_{0}: \mu_{i} \leq 3 \\
& H_{1}: \mu_{i} \succ 3
\end{aligned} \quad \mathrm{i}=1,2,3,4,5,6
$$

$\mathrm{H}_{0}=$ optimality of the six components of economic feasibility (advancement of innovation in products, reduction of waste in products, expansion of the market for products, advancement of the quality of products, competitive power of products, increase of revenue from products' sales) of the use of R \& D units in the construction industry.

$\mathrm{H}_{1}=$ non-optimality of the six components of economic feasibility (advancement of innovation in products, reduction of waste in products, expansion of the market for products, advancement of the quality of products, competitive power of products, increase of revenue from products' sales) of the use of $R$ \& D units in the construction industry.

According to Table 5, the mean of advancement on innovation factor in products is above the average level (3.581); the significance level $(\mathrm{p}=0.000<0.05)$ as the obtained statistic $t$ (4.897) are greater than the $t$ of the table (1.645). Therefore, $\mathrm{H}_{0}$ is rejected and $\mathrm{H}_{1}$ assuming that research and development increases innovation in products is proven. Besides, according to the findings, the mean of expansion of the market for products factor is above the average level (3.547); the significance level $(\mathrm{p}=0.000<0.05)$ and the obtained statistic $t$ (4.795) are greater than the $t$ of the table (1.645).

Table 5. Single-sample T-test related to the components of economic feasibility

\begin{tabular}{|c|c|c|c|c|c|}
\hline & Mean & $\begin{array}{c}\text { Standard } \\
\text { deviation }\end{array}$ & $\begin{array}{c}\text { Degree } \\
\text { of } \\
\text { freedom }\end{array}$ & $\mathrm{t}$ & $\begin{array}{c}\text { Significance } \\
\text { level } \\
(\mathrm{p})\end{array}$ \\
\hline $\begin{array}{c}\text { Advancement } \\
\text { of innovation } \\
\text { in products }\end{array}$ & 3.581 & 0.721 & 36 & 4.89 & 0.000 \\
\hline $\begin{array}{c}\text { Reduction of } \\
\text { waste }\end{array}$ & 3.497 & 0.730 & 36 & 4.14 & 0.000 \\
\hline $\begin{array}{c}\text { Expansion of } \\
\text { market }\end{array}$ & 3.574 & 0.728 & 36 & 4.79 & 0.000 \\
\hline $\begin{array}{c}\text { Advancement } \\
\text { of quality }\end{array}$ & 3.533 & 0.773 & 36 & 4.19 & 0.000 \\
\hline $\begin{array}{c}\text { Products' } \\
\text { competiti- } \\
\text { veness }\end{array}$ & 3.673 & 0.775 & 36 & 5.35 & 0.000 \\
\hline $\begin{array}{c}\text { Increase in } \\
\text { revenue }\end{array}$ & 3.778 & 0.850 & 36 & 5.56 & 0.000 \\
\hline
\end{tabular}

Therefore, $\mathrm{H}_{0}$ is rejected and $\mathrm{H}_{1}$ assuming that research and development increases the market for products in the domain of construction industry is proven. Also, the mean of reduction of waste in products factor is above the average level (3.497); the significance level $(\mathrm{p}=0.000<0.05)$ and the obtained statistic $t$ (4.147) are greater than the $t$ of the table (1.645). Therefore, $\mathrm{H}_{0}$ is rejected and $\mathrm{H}_{1}$ assuming that research and development leads to a reduction in product waste in the domain of construction industry is proven. The findings also demonstrate that the mean of advancement of products quality factor is above the average level (3.533); the significance level $(\mathrm{p}=0.000<0.05)$ and the obtained statistic $t(4.199)$ are greater than the $t$ of the table (1.645). Therefore, $\mathrm{H}_{0}$ is rejected and $\mathrm{H}_{1}$ assuming that research and development leads to the advancement of products' quality in the domain of construction industry is proven.

In addition, the mean of products' competitiveness factor is above the average level (3.673); the significance level ( $\mathrm{p}=$ $0.000<0.05)$ and the obtained statistic $t(5.350)$ are greater than the $t$ of the table (1.645). Therefore, $\mathrm{H}_{0}$ is rejected and $\mathrm{H}_{1}$ assuming that research and development leads the products' competitiveness in the domain of construction industry is proven. Also, according to the findings, the mean of increase of 
revenue from products factor is above the average level (3.778); the significance level $(\mathrm{p}=0.000<0.05)$ and the obtained statistic $t$ (5.565) are greater than the $t$ of the table (1.645). Therefore, $\mathrm{H}_{0}$ is rejected and $\mathrm{H}_{1}$ assuming that research and development results in the increase in the revenue from products in the domain of construction industry is proven.

Therefore, investigation of the six components of economic feasibility of R \& D units results in the conclusion that all the six factors have economic feasibility in the use of R \& D units in the construction industry.

\subsection{Prioritization of components of the effect of the establishment of $R \& D$ units on the construction industry}

In order to prioritize the components of the effect of the establishment of $\mathrm{R} \& \mathrm{D}$ units on the construction industry, Friedman test is employed. Table 6 illustrates the results of this test.

Table 6. Prioritization of factors of the effect of establishment of R \& D units on the construction industry

\begin{tabular}{|l|l|c|c|}
\hline Rank & \multicolumn{1}{|c|}{ Factors } & Mean & Mean rank \\
\hline 1 & $\begin{array}{l}\text { Existence of } \\
\text { physical } \\
\text { structures }\end{array}$ & 3.782 & 2.80 \\
\hline 2 & $\begin{array}{l}\text { Position of } \\
\text { cultural structures }\end{array}$ & 3.542 & 2.17 \\
\hline 3 & $\begin{array}{l}\text { Managers' } \\
\text { readiness }\end{array}$ & 2.908 & 1.02 \\
\hline
\end{tabular}

Significance level: 0.000

According to Table 6 , the components of the effect of the establishment of R \& D units on the construction industry as prioritized as follows: 1 . presence of physical structures, 2. the position of cultural structures, and 3. managers' readiness.

5.1 Prioritization of the components of the economic feasibility of the establishment of $R \& D$ units in the construction industry

In order to prioritize the components of the economic feasibility of the establishment of R \& D units in the construction industry, Friedman test is employed. Table 7 illustrates the results of this test.

Table 7. Prioritization of components of economic feasibility of establishment of R \& D units in the construction industry

\begin{tabular}{|l|l|c|c|}
\hline Rank & \multicolumn{1}{|c|}{ Factors } & Mean & Mean rank \\
\hline 1 & $\begin{array}{l}\text { Increase of revenue from } \\
\text { products }\end{array}$ & 3.778 & 5.14 \\
\hline 2 & $\begin{array}{l}\text { Products' } \\
\text { competitiveness }\end{array}$ & 3.673 & 3.74 \\
\hline 3 & $\begin{array}{l}\text { Advancement of } \\
\text { innovation in products }\end{array}$ & 3.581 & 3.38 \\
\hline 4 & $\begin{array}{l}\text { Expansion of market for } \\
\text { products }\end{array}$ & 3.574 & 3.28 \\
\hline 5 & $\begin{array}{l}\text { Advancement of quality } \\
\text { of products }\end{array}$ & 3.533 & 2.97 \\
\hline 6 & $\begin{array}{l}\text { Reduction of product } \\
\text { waste }\end{array}$ & 3.497 & 2.50 \\
\hline
\end{tabular}

Significance level: 0.000
According to Table 7, the components of economic feasibility of establishment of $\mathrm{R} \& \mathrm{D}$ units in construction industry are prioritized as follows: 1 .increase of revenue from products, 2 . products' competitiveness, 3 .increase of innovation in products, 4. expansion of market for products, 5. advancement of the quality of products, and 6 . reduction of product wastes.

\section{RESEARCH QUESTIONS}

Statistical investigation and analysis of the questionnaires point to some conclusions regarding the effect of the establishment of $\mathrm{R} \& \mathrm{D}$ units in organizations and corporations working in the field of construction industry, and the obstacles on their way. After investigation of the questions of this questionnaire, the challenges existing in research and development centers can be classified into the two categories of internal organizational problems and external organizational problems. Internal organizational problems include challenges such as shortage of facilities and manpower, official and financial problems (such as lack of financial independence, official bureaucracy, et.), and problems and challenges related to the researchers. External organizational problems include difficulties such as communicative problems of research and development centers with other sections, and issues related to the position of research and development in the society. Also, the results showed that establishment of R \& D units in the construction industry is economically feasible, and the position of cultural structures and existence of physical structures for R \& D units in the construction industry is effective. In this regard, with a systematic view, the issue of research culture is proposed as the central point of the model, and other issues are arranged in order of priority. In fact, it could be inferred that research culture can be defined as the sum of all factors related to research. In other words, as shown in Figure 1, research culture is the principal challenge to research in the developing countries.

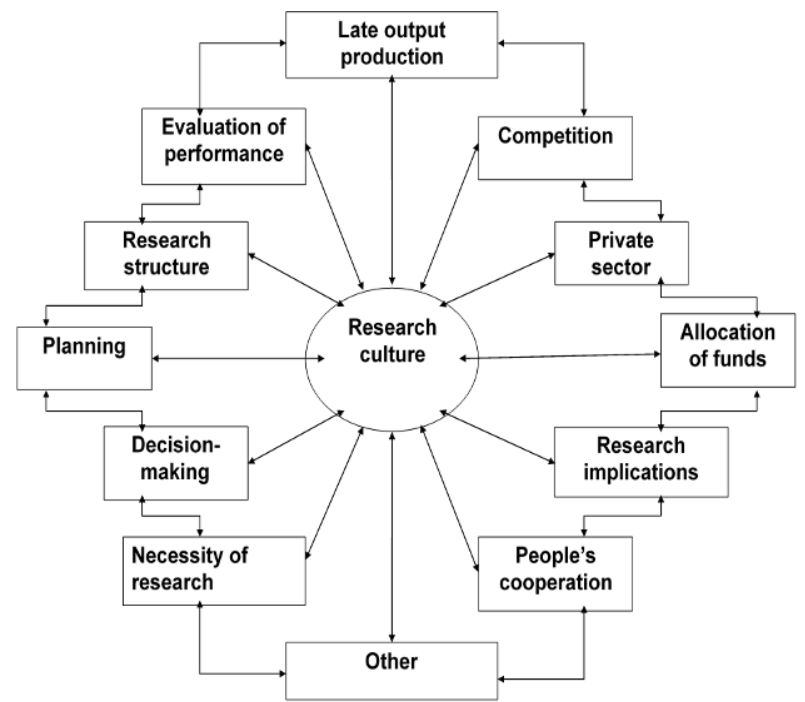

Figure 1. Research culture, a title for all problems related to research

As inferred form Figure 1, all factors and activities related to culture have a direct relation to research culture. This means that in order to advance research and science production the greatest attention must be paid to the advancement of research 
culture. Of course the relation of other factors to one another is important, too. The importance of research culture could perhaps be systematically shown as in Figure 2. This figure shows that the research culture is the pivot of a country's development. Therefore, attention must be aid to this issue in order to solve the problems and challenges to research and development in Iran.

\begin{tabular}{|c|c|c|}
\hline Input & Process & Output \\
\hline Resources & Research culture & Development \\
\hline \multirow[t]{2}{*}{$\begin{array}{l}\text { Human } \\
\text { resources } \\
\text { Ingredients } \\
\text { Financial } \\
\text { resources } \\
\text { Machinery }\end{array}$} & $\begin{array}{l}\text { Planning, decision- } \\
\text { making, assessment } \\
\text { system, implications of } \\
\text { research findings, } \\
\text { belief in the value of } \\
\text { research, research } \\
\text { structure, attention of } \\
\text { private and state } \\
\text { sectors and the public } \\
\text { to research, etc. }\end{array}$ & \multirow[t]{2}{*}{$\begin{array}{l}\text { Achievement } \\
\text { of objectives } \\
\text { determined in } \\
5 \text {-year plans } \\
\text { and the vision } \\
\text { bill, etc. }\end{array}$} \\
\hline & Feedback & \\
\hline
\end{tabular}

Figure 2. Systematic view of research: research culture, the pivot of the country's development

\section{References:}

Ali Ahmadi, A.R., 1998. Management of R \& D units, Islamic Azad University Press.

Behkish, M. M., 2002. In the context of economy globalization, Reed Publishing, second edition, Tehran.

Bosworth, D.L., 1993. Research and Development, London, published for the Royal Statistical Society and the Economic and Social Research Council (by) Chapman \& Hall

Gazrani, S., 1992. Newly industrialized countries of East Asia's development model and its application in the barriers, MS Thesis, Tehran.

Griliches, Z., 1980. Returns to R\&D expenditures in the private sector', in (eds) Kendrick, $\mathrm{K}$ and Vaccara, B, New Developments in Productivity Measurement.

Heininger, S. A., 1988. R\&D and Competitiveness-What Leaders Must Do. Research Technology Management, 31(6), pp.6-7.

McLaughlin, Greg pry C., 1995. Total quality in research and development, Delray Beach, Fla., St Lucie press.

Northrup, H.R., 1988. Professional women in R\&D laboratories. Research-technology management, 31(4), pp. 4452. doi: 10.1080/08956308.1988.11670535

Perry, S. and Grinaker, R., 1994. Earnings expectations and discretionary research and develop. Accounting Horizons, 8(4), pp. 43-51. doi: 10.17261/Pressacademnia.2015211510.
Salehi, E., and Banisi, S., 1996. Characteristics of R\&D Management in Japan, In the First Conference of Industries and Mines R\&D Centers, Iran.

Shahabadi, A., 2002. The effect of internal and external R \& D activities (through trade), the total productivity of factors of production, $\mathrm{PhD}$ thesis, Tarbiat Modarres University.

Shebli, K., 1996. Research and Development Management, Industrial Management Press, first edition. 